REVISTA DE ESTUDOS EM ARTES CÊNICAS

E-ISSN 2358.6958

\title{
O cultivo da arte dramática: A partir da filosofia existencial kierkegaardiana
}

\author{
Deise Abreu Pacheco \\ Lucas Piccinin Lazzaretti
}

\section{Para citar este artigo:}

PACHECO, Deise Abreu; LAZZARETTI, Lucas Piccinin. O cultivo da arte dramática: A partir da filosofia existencial kierkegaardiana. Urdimento - Revista de Estudos em Artes Cênicas, Florianópolis, v. 3, n. 42, dez. 2021.

do) DOI: http:/dx.doi.org/10.5965/1414573103422021e0206

Este artigo passou pelo Plagiarism Detection Software | iThenticate 
O cultivo da arte dramática:

A partir da filosofia existencial kierkegaardiana ${ }^{1}$

Deise Abreu Pacheco²

Lucas Piccinin Lazzaretti ${ }^{3}$

\section{Resumo}

O presente artigo pretende analisar de que maneira as reflexões do filósofo dinamarquês Søren Kierkegaard (1813-1855) sobre a relação entre comunicação e existência podem servir como base conceitual para se desenvolver uma consideração a respeito do cultivo da arte dramática. Opondo as formas comunicativas objetivas àquelas da subjetividade, Kierkegaard vale-se do conceito de primitividade como forma de indicar um modo de ser em que os indivíduos se encontram diante do fenômeno de suas próprias existências. Utilizando reflexões teórico-práticas em pedagogia do teatro de Stanislávski, Knebel e Ward, buscaremos indicar como essa abordagem kierkegaardiana permite compreender o cultivo da arte dramática sob uma ótica existencial-comunicativa.

Palavras-chave: Filosofia existencial. Pedagogia do teatro. Arte dramática. Primitividade. Søren Kierkegaard.

${ }^{1}$ Revisão ortográfica e gramatical do artigo realizada por Ana Cláudia Romano Ribeiro. Doutorado em Teoria e História Literária pela Universidade Estadual de Campinas. Mestre pela mesma universidade. Graduação em Letras pela Universidade Federal de Juiz de Fora.

(3ttp://lattes.cnpa.br/9815025268221797

2 Doutorado em Artes Cênicas (Bolsa FAPESP/Capes, processo no 2014/04101-9) pela Escola de Comunicações e Artes da Universidade de São Paulo (ECA/USP), com estágio de pesquisa doutoral em filosofia no Søren Kierkegaard Research Centre (SKC), da Universidade de Copenhague (Dinamarca, 2015/BEPE/FAPESP, processo no 2015/00330-6). Mestrado em Artes Cênicas pela mesma universidade. Graduada em Direção Teatral e mestrado em Artes Cênicas (ECA/USP). Professora Visitante do Programa de Pós-Graduação em Escrita Criativa da Fundação Armando Álvares Penteado (FAAP). dedeista@gmail.com

http://lattes.cnpq.br/9316682687985606 id https://orcid.org/0000-0001-7732-161X

3 Pós-Doutorando no Instituto de Estudos da Linguagem (IEL) da Universidade Estadual de Campinas (UNICAMP)-(Bolsa FAPESP, n. do processo: 19/27014-8). Doutorado em Filosofia pela Pontifícia Universidade Católica do Paraná (2019). Mestrado em Filosofia pela Pontifícia Universidade Católica do Paraná (2015). Graduação em Direito pelo Centro Universitário Curitiba (2012). Recebeu a Kierkegaard House Foundation Fellowship no período de 2018/2019 na Hong-Kierkegaard Library em St. Olaf, Northfield, onde também este como visiting scholar (2017) e como Summer Fellow researcher (2014). Lucasplazzaretti@hotmail.com

(9) http://lattes.cnpq.br/4483346346539475 (iD https://orcid.org/0000-0002-3791-4151 


\title{
The cultivation of dramatic arts: \\ Based on kierkegaardian existential philosophy
}

\begin{abstract}
This article analyses the way in which Danish philosopher søren Kierkegaard's (1813-1855) reflections on the relationship between communication and existence can function as the conceptual foundation for developing a consideration on the cultivation of dramatic arts. Opposing objective communicative forms to those of subjectivity, Kierkegaard makes use of the concept of primitivity as a means of indicating a way of being in which individuals are faced with the phenomenon of their own existence. This article employs theoretical-practical reflections within theatre pedagogy as proposed by Stanislávksi, Knebel and Ward in order to point to the way in which this Kierkegaardian approach allows one to understand the cultivation of the dramatic arts under an existential-communicative light.
\end{abstract}

Keywords: Existential philosophy. Theatre pedagogy. Dramatic arts. Primitivity. Søren Kierkegaard.

El cultivo del arte dramático:

Desde la filosofía existencial de Kierkegaard

\section{Resumen}

El presente artículo pretende analizar cómo las reflexiones del filósofo danés Søren Kierkegaard (1813-1855) sobre la relación entre comunicación y existencia pueden servir de base conceptual para desarrollar una consideración sobre el cultivo del arte dramático. Oponiendo las formas comunicativas objetivas a las de la subjetividad, Kierkegaard utiliza el concepto de primitividad como forma de indicar un modo de ser en el que los individuos se enfrentan al fenómeno de su propia existencia. A partir de reflexiones teóricas y prácticas sobre la pedagogía teatral de Stanislavski, Knebel y Ward, trataremos de indicar cómo este enfoque kierkegaardiano permite entender el cultivo del arte dramático desde un punto de vista existencial-comunicativo.

Palabras clave: Filosofía existencial. Pedagogía teatral. Arte dramático. Primitivismo. Søren Kierkegaard. 
Kierkegaard, em uma de suas primeiras reflexões presentes em seu conjunto de notas sobre $A$ dialética da comunicação ética e ético-religiosa, ${ }^{4}$ afirma que, conforme sua leitura, a modernidade esqueceu-se o que é um ser humano (SKS 27, 290; Papir 365-4). Tal "esquecimento do ser humano", na concepção kierkegaardiana, é atribuída à falta de primitividade, termo proposto como uma oposição à noção de progresso tipicamente moderna. ${ }^{5}$ Mais do que uma oposição à generalista ideia de progresso, o conceito de primitividade se apresenta como um valor positivo que se contrapõe àquilo que o autor compreende por desonestidade [no dinamarquês, Uredelighed] dos tempos modernos. Essa desonestidade epocal vincula-se, por sua vez, à sua crítica ao esquecimento moderno da distinção entre arte e ciência. Com essa crítica, Kierkegaard busca fundamentalmente chamar a atenção para apropriação indevida que a filosofia pós-kantiana faz do ético, assimilando-o ao domínio da ciência (no dinamarquês, Videnskab), ou seja, tornando-o objeto de

\footnotetext{
${ }^{4}$ Doravante adotaremos a norma internacional para citação da obra de Kierkegaard, que solicita a inclusão da referência ao texto original em dinamarquês. Assim, aplica-se a referência às obras completas do autor designadas pela sigla SKS (Søren Kierkegaards Skrifter). Trata-se de 28 volumes de texto original e 28 volumes de comentários, identificados pela sigla SKS K, organizados por Niels Jørgen Cappelørn, Joakim Garff, Jette Knudsen, Johnny Kondrup, Steen Tullberg, Anne Mette Hansen e Tonny Aagaard Olesen para a publicação da quarta edição das obras do autor, principiada em 1997 pela editora G. E. C. Gads Forlag de Copenhague, tendo sido concluída em 2013, em homenagem ao bicentenário de nascimento de Søren Kierkegaard. Empregamos sua última versão (1.8.1, 2014) disponível pelo acesso eletrônico: http://www.sks.dk/. A referência constará dos escritos do autor pela abreviatura: SKS, seguida, em algarismo arábico, do número do respectivo volume e página da obra em questão. No caso de $A$ dialética da comunicação ética e ético-religiosa (SKS 27, 389, página de abertura) também acrescentaremos o respectivo número que identifica o manuscrito (Papir 364, por exemplo), com tradução de Lucas P. Lazzaretti diretamente da língua dinamarquesa, não tendo sido ainda publicado em português. Essa obra refere-se a um conjunto de textos esboçados acerca de uma série de doze palestras sobre a dialética da comunicação que Kierkegaard tinha a intenção de realizar. Contudo o trabalho com as palestras não foi levado adiante, sendo que os esboços foram reunidos sob o título de $A$ dialética da comunicação ética e ético-religiosa para servirem a um projeto de livro, que veio a ser posteriormente lançado com o título de Discursos Cristãos (1848). Os esboços reunidos são constituídos por sete unidades manuscritas separadas, ou seja, quatro partes com rascunhos soltos (Papir 365, 366, 367 e 368) e duas partes, cada uma com sua própria seção menor, a saber, Papir 369 (Introdução) e Papir 370 (O Primitivo - o tradicional). Por fim, o último conjunto de manuscritos, Papir 371, contém a transcrição de Kierkegaard de sua primeira aula/palestra e de metade da segunda (Cf. SKS K 27, 289,1).
}

${ }^{5}$ A influência schilleriana sobre o conceito kierkegaardiano de primitividade é evidenciada pelo próprio autor que, em suas tentativas de explicitar os meandros de seu conceito, continuamente faz referência ao conceito de ingenuidade [em dinamarquês, Naivitet] presente no famoso ensaio Poesia ingênua e sentimental. É importante pontuar que, muito embora Kierkegaard esteja considerando questões pertinentes à estética nas anotações acima indicadas, sua compreensão sobre a "ingenuidade" extrapola aqueles indicados por Schiller. 
conhecimento especulativo. Tal conversão do ético em um objeto de conhecimento especulativo teria como consequência a dissociação entre este âmbito e o traço filosófico-existencial que lhe é, segundo Kierkegaard, inerente e fundamental. Em sua tentativa de expor uma diferenciação para essa forma de tratamento do ético, Kierkegaard baseia a sua abordagem sobre o ético pela via de uma apercepção (no dinamarquês, Realisation), dessa maneira distinguindo o ético como uma forma de conhecimento que se expressa enquanto capacidade potencial, um saber-fazer.

O que é de fato o ético [det Ethiske]? - Sim, se pergunto dessa maneira, então estou perguntando pelo ético de forma a-ética [u-ethisk], então estou perguntando da mesma maneira que a confusão dos tempos modernos o faz, e assim não consigo parar. O ético pressupõe que todo ser humano sabe o que é o ético, e por quê? Porque o ético pressupõe que todo ser humano deve percebê-lo a todo instante, mas então para isso ele deve certamente conhecê-lo. O ético não começa com a ignorância, a qual deve ser transformada em conhecimento, mas começa com um conhecimento e requer uma apercepção [Realiseren] (SKS 27, 393; Papir 365:7, itálicos nossos).

Com efeito, é na qualidade de uma apercepção cuja capacidade é compreendida como potência/possibilidade [no grego, Kata dýnamin] ${ }^{6}$ em cada ser humano, que o ético pode ser comunicado enquanto arte?. De forma análoga, Kierkegaard aponta que a noção de arte [no dinamarquês, Kunst], por seu turno, ao ser restringida estética e cientificamente pela concepção moderna de belasartes (pintura, escultura, música e literatura) ${ }^{8}$ passa a ser determinada pelos cânones da obra de arte e, dessa forma, também é esquecida em sua perspectiva ética.

${ }^{6}$ Conceito retirado da filosofia de Aristóteles, empregado por Kierkegaard em um sentido de potência ou possibilidade.

7 A concepção kierkegaardiana de arte foi influenciada pelos debates filosóficos suscitados pela tradição alemã precedente. Dessa maneira, arte é aqui compreendida tanto como um fazer artístico específico (pintura, literatura, etc.), como também é entendida, em um sentido mais amplo e metafísico, como uma espécie de disposição do sujeito artista e do objeto de arte em relação ao campo de seu acontecimento e em relação aos outros âmbitos da cultura. Há, para Kierkegaard, uma vinculação muito imediata entre a noção de arte e a noção de um saber-fazer, de tal maneira que a arte não é tomada por Kierkegaard em uma apreensão platônica ou neoplatônica, no sentido de uma referência a um ideal transcendental, mas é, ao contrário, algo vinculado à imanência da existência. A arte não é uma expressão da existência, mas é, no artista, a própria existência, da mesma maneira que o poético, o ético, o religioso e outros modos de ser se apresentam em cada indivíduo singular.

${ }^{8}$ Cf. Texto de comentário SKS K 27, 390, 25. 
o que se esqueceu. ${ }^{9}$ A distinção entre arte e ciência. Tudo se tornou ciência, a arte é entendida apenas esteticamente como belas-artes. Mas há todo um lado da arte de que a ciência se apossou, ou quer se apossar, que é o ético.

O ético se relaciona indiferentemente ao conhecimento [Viden], isto é, ele assume que todo ser humano o conhece.

É confuso quando o que deve ser comunicado como ciência é comunicado como arte (o escolasticismo é um exemplo), ${ }^{10}$ mas também quando o que deve ser comunicado como arte é comunicado como ciência, e aqui está a confusão nos últimos tempos, em que se comunica o ético como ciência. (SKS 27, 390; Papir 365:5, ênfases nossas).

A preocupação kierkegaardiana com a elaboração de uma "dialética da comunicação" abrange, então, um âmbito de entrecruzamentos conceituais em que os modos de ser (estético, ético e religioso) são confrontados com os modos de fazer (artístico, científico, pragmático), confrontação essa que existe apenas no horizonte do existencial e, portanto, em relação ao indivíduo singular [Enkelt]. O conceito de primitividade é trazido por Kierkegaard como uma forma de permitir ao indivíduo singular colocar-se em uma relação com sua própria existência, de tal maneira que essa existência não seja constituída pelas mediações e determinações externas da cientificidade.

Como decorrência dessa conjuntura filosófico-conceitual, Kierkegaard irá ocupar-se, pois, de formular um novo conceito de comunicação (SKS 27, 395; Papir 365:9), cuja dialética levará à dissolução das determinações de comunicador, objeto e receptor. (SKS 27, 393; Papir 365:7). Com essa articulação, o autor interpelará a diferença entre comunicar algo como arte e comunicar algo como ciência (SKS 27, 395; Papir 365:9), tornando a tópica da comunicação o centro nevrálgico da discussão sobre o esquecimento moderno acerca do que é um ser humano. Contudo, tal articulação só se faz possível quando Kierkegaard pensa a comunicação como uma arte ou uma prática que cada indivíduo singular tem de realizar continuamente. Nesse sentido, a capacidade de comunicar algo como arte implica necessariamente um aprendizado no campo prático. Esse

${ }^{9}$ O texto original principia exatamente dessa forma.

10 Escolasticismo aqui tem o sentido de academicismo de tipo cientificista, tão criticado por Kierkegaard, mas também diz respeito aos pensadores escolásticos do período medieval, identificados pelo filósofo dinamarquês como autores - como Tomás de Aquino - que visavam conciliar a fé cristã com a construção de um sistema de pensamento racional. 
caráter traz consigo uma abertura temática para campos que vão além da filosofia, permitindo assim um diálogo tanto com os saberes estéticos específicos, quanto com as modalidades de aprendizado e de comunicação desses saberes.

Dentre todas as possíveis vinculações que o aspecto prático tem com o artístico e com a arte, a prática teatral é sem dúvida aquela que parece possuir em si essa ligação de forma mais essencial. Kierkegaard não apenas compreendia tal peculiaridade como admirava profundamente a arte dramática precisamente porque, como afirma o filósofo, "na tensão teatral [a] angústia", normalmente vivida pelos indivíduos em suas existências cotidianas, "transforma-se em potenciação"11 (SKS 14, p.99; Lazzaretti, p.280).

Essa análise kierkegaardiana em muitos sentidos encontra ecos nas próprias reflexões sobre a atuação cênica. Konstantin Stanislávski pontua que, considerando alguns personagens e textos dramáticos, esses "são tesouros extraordinariamente delicados, complexos e dificilmente alcançáveis", sendo que, para tocá-los, "é preciso cavar fundo na alma do ator e no personagem para encontrá-los", de tal modo que se deve encontrar os meios "para penetrar nos recônditos lugares onde se encontram as riquezas espirituais” (Stanislávski, 2010, p.324). A preocupação com a interioridade em relação à criação, à comunicação, à expressão - e em oposição ao superficial, ao artificial e inautêntico - está presente na pedagogia do teatro assim como está presente na reflexão kierkegaardiana sobre a existência. Considerando então essa abertura temática e partindo de uma análise das contribuições feitas pelo filósofo dinamarquês com relação à dialética da comunicação, o presente trabalho visa averiguar de que maneira conceitos como primitividade e comunicação indireta podem servir para uma reflexão sobre o cultivo da arte dramática em uma perspectiva pedagógica, que valorize a singularidade dos indivíduos, sustentando como centro uma

11 Kierkegaard redigiu o ensaio A crise e uma crise na vida de uma atriz em 1847, no mesmo ano em que desenvolveu a redação de suas anotações sobre $A$ dialética da comunicação ética e ético-religiosa. A proximidade entre estes textos não é apenas temporal, guardando também uma intersecção temática, pois a questão sobre a comunicação indireta é explorada, ainda que de forma velada, na análise que faz o filósofo sobre o esforço existencial implicado na atuação dramática. Kierkegaard considerou que o texto de A crise e uma crise na vida de uma atriz deveria ser entendido como sendo de um espectro estéticoreligioso, o que, nos termos kierkegaardianos, significa um aprofundamento na análise do caráter existencial. 
prática existencialmente relevante.

\section{Da primitividade: O ressoar de uma voz própria}

A noção de primitividade, do latim primus, encontra na língua dinamarquesa e no ambiente lexical da obra de Kierkegaard os termos sinônimos "o primeiro" [den forste], "originalidade" [oprindelighed] e "autenticidade" [æegthed].12 universo semântico de tais termos já nos oferece algum vislumbre acerca do enquadramento conceitual que o autor confere a essa noção. Para Kierkegaard, a experiência da primitividade nos leva efetivamente a uma revisão do fundamental (SKS 27, 430; Papir 371:2). Essa revisão pressupõe, de um lado, o recuo frente a hábitos e costumes entronizados, próprios a uma abordagem generalizante e impessoal da experiência humana, e, de outro, a abertura ao desenvolvimento de aspectos sui generis da vida humana que singularizam a existência concreta de cada indivíduo. Sob a perspectiva da generalidade e da impessoalidade, o autor reputa a falta de primitividade às transformações sócioeconômicas, culturais e políticas que, em meio ao ideário do progresso histórico, ao longo do século XIX, engendram a intensificação do crescimento urbano, coma expansão dos meios de comunicação de massa e do cientificismo, produzindo uma concepção abstrata da existência humana, na qual a ideia de multidão [no dinamarquês, Mængde] é paradigmática. Na multidão, a experiência humana é reduzida ao anonimato, podendo ser comparada a uma espécie de adesão irrefletida ao universo de hábitos e costumes sociais, cuja conveniência é conferir segurança normativa ao indivíduo: "[...] em qualquer lugar, unir-se ao tradicional, fazer tal como os outros, pensar e falar como os outros [...]" (SKS 27, 430; Papir 371:2). Nesse sentido, os meios de comunicação, que têm na multidão seu alvo, dissolvem a dimensão de realidade efetiva [no dinamarquês, Virkelighed] que sustenta a autenticidade da linguagem oral e, igualmente, da prática literária, pois apelam à manifestação grandiloquente de uma expressão geral e abstrata, por exemplo, a "voz da época" [no dinamarquês, Tidens Røst] (SKS 27, 400; Papir, 266: 2): 
Se alguém, quando quisesse falar, tivesse um megafone que fosse tão alto que pudesse ser ouvido em todo país: logo ele desenvolveria a impressão fantasiosa de que ele não era um ser humano singular (mas algo muito maior, por exemplo, a voz da época, etc., o Abstrato) e que ele não falava com um ser humano singular, mas com o mundo todo [...] (SKS 27, 400; Papir, 266: 2, ênfases nossas).

A quem pertenceria essa "voz da época"? Quem seria o emissor dessa voz? E com quem essa voz estaria a falar? Para Kierkegaard, é fato que tamanha grandiloquência e abstração comunicativa tem por consequência deletéria, tendo em vista o princípio ético da comunicação como arte, a dissolução da realidade efetiva do individuo singular [em dinamarquês, den Enkelte] enquanto portador de uma voz pertencente a um ser humano concreto. A noção de "indivíduo singular" é uma das categorias centrais do pensamento do autor escandinavo. O termo dinamarquês den Enkelte é usualmente traduzido para a língua portuguesa por "indivíduo singular" para destacar o sentido de "único" presente na língua de partida. ${ }^{13}$ Todavia, se quiséssemos ser mais literais, caberia dizermos: o indivíduo no singular. Logo, essa acepção de individualidade humana, que opõe a noção de indivíduo a toda e qualquer generalidade, vai ao encontro do campo lexical peculiar à noção de primitividade, identificada às concepções de "primeiro", "original” e "autêntico".

Tal primitividade, no sentido de uma originalidade ou de uma autenticidade, não é entendida por Kierkegaard como uma essencialidade. O que há de fundamental é antes uma relação ou uma disposição relacional do que necessariamente um reenvio a uma substância, uma natureza ou uma essência pré-determinadas. Valendo-se de termos próprios do mundo literário, Kierkegaard aponta para o fato de que o "autêntico gênio primitivo" é uma espécie de "Revisor-Geral" [em dinamarquês, General-Revisor], isto é, um indivíduo responsável por analisar e revisar todos os elementos relacionais da existência tanto em sua superficialidade quanto em sua profundidade, tanto em sua imediatidade quanto em sua mediação, de tal modo que "cada existente primitivo também contém”, em sua existência e em sua atividade voltada para a primitividade, "uma revisão do ser humano em geral" (SKS 27, 399; Papir 266:1).

13 Essa escolha tradutória está em consonância à forma consagrada pela recepção do autor em língua inglesa que, frequentemente, traduz o termo por "single individual". 
Trata-se, aqui, como em boa parte do esforço filosófico kierkegaardiano, de indicar que o acesso ao fenômeno da existência não pode ser feito por uma mediação abstrata-conceitual. A primitividade é uma potência que se revela em cada indivíduo precisamente na sua relação com singularidade.

Nessa perspectiva, a revisão do fundamental preconizada pela ideia de "primitivo", orienta-nos no sentido de uma investigação existencial, ou seja, nos confronta com aquilo que Kierkegaard compreenderá como a importância da assunção de um eu-pessoal [no dimanarquês, det personlige jeg], cujo símbolo pode ser dimensionado pela expressão efetiva de uma voz própria. ${ }^{14}$ Mas no que consistiria a expressão de uma voz própria?

Essa indagação conduz precisamente ao centro de nossa abordagem, na qual pretendemos interpelar o conceito de primitividade, articulando-o a fundamentos da arte dramática. Em A dialética da comunicação ética e éticoreligiosa, Kierkegaard faz alusão à palavra latina persona, sugerindo tanto a sua acepção semântica de "soar através de", "ressoar", bem como a sua referência emblemática à máscara [no grego, prosopon], adereço essencial da indumentária no teatro grego antigo, em que uma das funções principais era de amplificar o som da voz do ator:15 "A persona da antiguidade - per sonare - potencializar a voz do indivíduo singular enquanto ele, no entanto, é a voz do indivíduo singular" (SKS 27, 400; Papir, 266:2). Assim, ao aludir à noção de persona, Kierkegaard aponta para a função arcaica da máscara grega ${ }^{16}$ de amplificar a voz do ator enquanto individuo singular, enfatizando, todavia, a permanência da qualidade existencial que faz ressoar por via da persona: sua voz permanece sendo a voz

${ }^{14}$ O comentador K. Brian Söderquist defende que Kierkegaard, já em sua tese intitulada Sobre o Conceito de Ironia constantemente referido a Sócrates (1841), ou seja, em uma obra que antecede em seis anos a redação do escrito que estamos a abordar, Kierkegaard está tateando a noção de primitividade no âmbito de uma antropologia filosófica, articulando-a ao reconhecimento de uma voz peculiar da individualidade, a partir da ideia de originalidade, de um "si-mesmo original", i.e., primitivo, primevo: "In short, Kierkegaard presupposes that the original conditions for the possibility of becoming a self - one's own unique self are potentially present from the beginning as a part of the self. He writes that a person who has respect form 'a human being's worth and... a sense for the originality in human being', will 'silently and quietly listen to the voice of what is peculiar [det Eiendommeliges Stemme] in individuality' will 'spy its movements in order to dispose over it' and let 'the individual develop harmoniously into a pliable, complete form"” (Söderquist, 2007, p. 158, ênfases nossas).

${ }^{15}$ Cf. Texto de comentário SKS K 27, 400M,26.

${ }^{16}$ A máscara grega antiga era geralmente feita de linho revestido de estuque, sendo prensada em moldes de terracota, possibilitando a amplificação da voz, conferindo tanto ao rosto como às palavras um efeito distanciador (Berthold, 2001, p.114). 
do individuo singular [no dinamarquês, den Enkeltes Røst], concomitante ao fato de que o caráter ou personalidade comunicada pelo ator pertence a personagens dramáticas [no latim, dramatis personae] ou ao papel.

\begin{abstract}
During the Classical period The Ancient Greeks used the same word for the mask and the human face, the word Prosopon. The word Prosopon is etymologically composed by the preposition pros - that means at, towards, for; and the word ops - which in Homeric Greek means hole, eye, gaze, opening, pupil, voice, word, speech. Prosopon means: face, that which is before our eyes, between eyes that see each other - but also personality, dramatic persona, mask.

The word contains the relationship between two subjects, pointing towards a dialogue, a reflection, contemplation, a meeting or an opposition with the other.

In the mental universe of Ancient Greece there was no distinction between the mask and the face.

The mask was another face and not an object that conceals and covers the human face. The idea of concealment, that is, the mask as something that hides the true face was developed later in Europe, as a result of the monotheistic religions and the Christian civilization (Vovolis, 2009, p.31, ênfases nossas em negrito).
\end{abstract}

Portanto, na concepção grega antiga do termo prosopon, encontramos uma conexão orgânica entre a máscara e a face humana que instaura uma relação dialógica entre duas perspectivas; a máscara apresenta-nos uma outra face, sem pretender ocultar a realidade efetiva da individualidade daquele que a anima. Nesse sentido, a noção de persona ${ }^{17}$ pode ser compreendida enquanto o ressoar da voz própria do ator que é amplificada por meio da perspectiva de uma outra face, de um outro caráter, i.e., do personagem dramático. Com efeito, destacamos a seguinte definição para o verbete Dramatis personae do Dicionário de Teatro (1999), de Patrice Pavis (1999, p.112, ênfases nossas em negrito).

É significativo notar que a palavra latina persona (máscara) é a tradução da palavra grega para "personagem dramática" ou "papel". Dessa forma, a personagem é originalmente concebida como uma voz narrativa; é um duplo do homem "real". Os gramáticos usaram em seguida a imagem de máscara e do drama para caracterizar as relações entre as três 
pessoas: a primeira (eu) desempenha o papel principal, a segunda (tu) dá-lhe a réplica, ao passo que o ele, que não é definido em termos de pessoa no intercâmbio entre eu e tu, é o sujeito dos diálogos.

Tendo em vista tais distinções e arrazoados, a questão acerca de em que consistiria a expressão de uma voz própria, nos coloca diante do problemachave da dialética da comunicação ética e ético-religiosa conforme elaborada por Kierkegaard. Essa comunicação define-se substancialmente por ser indireta; assim como a voz do ator ressoa por meio da máscara teatral, também a comunicação autenticamente ética dependerá da função estética de uma persona, i.e., de uma máscara. Essa função estética está, por sua vez, primitivamente associada a uma voz narrativa, ao duplo do indivíduo no singular.18 Desse modo, a investigação existencial por meio da noção de primitividade, que pressupõe uma revisão do fundamental, nos posicionará frente a frente à persona de um eu-pessoal. Se do ponto de vista gramatical e retórico, esse "eu" será identificado à primeira pessoa do singular, do ponto de vista da arte dramática, será identificado à segunda pessoa, ao "tu" ou "você", pois, como visto, a persona faz ressoar a voz própria do "eu" por meio de outra face. ${ }^{19}$ Logo, o ressoar da voz própria, que é o próprio soar da primitividade do indivíduo no singular, está fundamentalmente enraizada na expressão de um eupessoal que se manifesta dialeticamente por uma comunicação que faz entrever o "eu" por via do "você", ou seja, de um outro.

Se tomarmos essa premissa dramática para discutirmos à dialética da comunicação ética e ético-religiosa, a assunção do eu-pessoal dependerá

${ }^{18} \mathrm{~A}$ dupla reflexão [Fordoblelse] é um tema caro à filosofia kierkegaardiana, sendo um dos pontos fundamentais de sua dialética. Por postular uma crítica ao que considera como a primeira imediatidade onde o indivíduo é determinado pela exterioridade imediata - e, de igual maneira, ao que considera como a primeira reflexão - onde o indivíduo é determinado por uma mediação abstrata -, Kierkegaard postula que a dupla reflexão é aquela que permite ao indivíduo pôr-se em uma relação imediata com sua própria singularidade. Esse tema é explorado pelo pseudônimo Johannes Climacus no segundo capítulo da segunda parte de Pós-escrito conclusivo não-científico às Migalhas Filosóficas, no capítulo que trata precisamente "da verdade subjetiva", da "interioridade" e, por conseguinte, da postulação filosófica de que "a verdade é a subjetividade" (SKS 7, p. 173 ss.). Para maiores considerações sobre a relação entre "dupla reflexão" e comunicação indireta, cf. Lübcke, 1990, p.31-40.

${ }^{19}$ Anatol Rosenfeld assim esquematiza essa correlação pronominal no âmbito dos gêneros literários: "Se o pronome da Lírica é o Eu e da Épica o Ele, o da Dramática será o Tu (Vós etc.). O tempo dramático não é o presente eterno da Lírica e, muito menos, o pretérito da Épica; é o presente que passa, que exprime a atualidade do acontecer e que evolve tensamente para o futuro" (Roselfeld, 2000, p. 34, nossa ênfase). 
essencialmente de uma educação que seja formativa no âmbito da comunicação indireta, ou seja, de uma educação que compreenda a importância do cultivo da qualidade primitiva do que venha a ser comunicar-se por meio de uma voz própria.

\section{Da comunicação indireta: Ética e estética no cultivo da arte dramática}

A abordagem estético-pedagógica que estamos a propor, tendo em vista a interpelação do conceito de primitividade e, com ele, das noções de estética e de ética, a partir dos escritos de A dialética da comunicação ética e ético-religiosa, de Søren Kierkegaard, pretende indicar como certos fundamentos da arte dramática, pelo viés da pedagogia do teatro, ${ }^{20}$ vão ao encontro de uma educação que seja formativa no âmbito da comunicação indireta, i.e., que compreenda a importância do cultivo de uma voz própria que se propaga pela criação de disposições relacionais indiretas e múltiplas, nos termos sugeridos na seção acima.

A verdadeira comunicação e instrução em relação ao ético e ao éticoreligioso é educativa [Opdragelse]. Ao ser educada, a pessoa se torna aquilo que é essencialmente considerada para ser [...]. A educação começa considerando-se que se deve educar alguém enquanto sendo $\varkappa \alpha \tau \alpha \delta u v \alpha \mu v^{21}$ o que ele deveria ser, e, tomando-o sob essa consideração, o professor tira isso de dentro dele. Ele o puxa para cima, e assim está lá, - (um cultivar [op-elske] a planta, um educar [op-drage] a criança) (SKS, 27, 402; Papir 366:3, ênfases do autor).

Nesse trecho, Kierkegaard utiliza uma série de jogos de palavras que não

20 No programa de Pós-Graduação em Artes Cênicas da Escola de Comunicações e Artes (ECA) da Universidade de São Paulo (USP), a Pedagogia do Teatro é uma das áreas de concentração, sendo dividida em duas linhas de pesquisa: Formação do Artista Teatral; Teatro e Educação. "Dentro da área da Pedagogia do Teatro agrupam-se as pesquisas de pós-graduação que tratam dos diversos aspectos que caracterizam a relação entre o Teatro e a Pedagogia, compreendendo tanto as investigações que se ocupam do caráter educacional da prática teatral, quanto aquelas voltadas para os princípios e métodos de ensino e aprendizagem do teatro em circuitos profissionais e amadores. Esta área de concentração, portanto, abrange pesquisas que enfocam a prática teatral enquanto experiência relevante na formação do indivíduo, e também os processos voltados para o aprimoramento técnico e reflexivo do artista de teatro" (cf. http://www3.eca.usp.br/ppgac/linhas-de-pesquisa). Para um tratamento detalhado do tema, enquanto área que extrapola o âmbito curricular da USP, evidenciando a ampla consagração dessa noção no contexto das artes cênicas no Brasil, cf. Koudela, Almeida Jr., 2015.

${ }^{21}$ Em grego no original: kata dýnamin, conceito retirado da filosofia de Aristóteles, empregado por Kierkegaard em um sentido de potência ou possibilidade. 
podem ser reproduzidos em português. O verbo dinamarquês opdrage (educar) é formado pela raiz drage, verbo que significa o "ato de mover", "arrastar" ou "puxar algo ou alguém", acrescido do prefixo op, advérbio que significa algo "acima" ou "em direção ao alto". Assim, o verbo educar significaria, se tomado em sua forma literal, o ato de puxar ou mover alguém para cima, jogo esse que o autor reproduz. Além disso, o filósofo também joga com a estrutura de outra palavra, opelske, a qual significa cultivar e tem em sua raiz o verbo elske (amar). Desse modo, ao aproximar o sentido dos termos cultivar e educar, Kierkegaard salienta que, em um processo formativo por meio da comunicação indireta (e, portanto, ética), o indivíduo deve ser considerado singularmente em sua potencialidade, i.e., "ao ser educada, a pessoa se torna aquilo que é essencialmente considerada para ser" (SKS, 27, 402; Papir 366:3). Tais considerações estão em consonância com uma concepção do ético que, conforme já observado, assenta-se no plano da apercepção (no dinamarquês, Realisation), uma vez que distingue o ético como uma forma de conhecimento que se expressa enquanto capacidade, um saber-fazer. Com efeito, é na qualidade de uma apercepção cuja capacidade é compreendida como potencial em cada ser humano, que o ético pode ser comunicado enquanto arte. Nesse sentido, a tarefa do professor será de cultivar esse movimento de "dentro para fora", levando à realização efetiva da capacidade individual. Em certo sentido, a tarefa do professor é de fazer despertar a primitividade enquanto uma potência reconhecida pelo indivíduoaluno em sua relação com essa potencialidade e, portanto, com sua singularidade.

No âmbito da arte dramática, destacaremos duas vertentes de pesquisa pioneiras no campo da atuação cênica, ambas em curso na primeira metade do século XX, cujos princípios estético-pedagógicos nos permitem associá-las a pressupostos da dialética da comunicação ética, pensada à luz dos escritos de Kierkegaard. A primeira vertente diz respeito à profunda mudança de perspectiva estética na área da formação do ator e da cena teatral ocorrida em virtude do trabalho do encenador-pedagogo 22 e ator russo Konstantin Serguêievitch

22 Na história do teatro, a noção de encenador-pedagogo enquanto uma pedagogia teatral está fundamentalmente associada à pesquisa de Stanislávski, embora na produção teatral russa do final do século XIX e das primeiras décadas do século XX haja proposições e perspectivas pedagógicas muito 
Stanislávski (1863-1938). A segunda vertente concerne à atuação da educadora estadunidense Winifred Louise Ward (1884-1975), supervisora de Dramatização nas escolas públicas de Evanston (Illinois, EUA) e professora de Arte Dramática na Northwestern University, que estabeleceu os princípios do que nomeia de Drama Criativo [no inglês, Creative Dramatics], constituindo-se como precursora da autonomia epistemológica da arte dramática conquistada pela área de pesquisa em Teatro-Educação. Em ambas as vertentes, todavia, é possível verificarmos uma preocupação comum comprometida com uma radical revisão do fundamental (SKS 27, 430; Papir 371:2), ou seja, voltada à investigação de fundamentos éticos no âmbito da criação teatral enquanto processo formativo, e, nesse sentido, relevante para a discussão acerca da noção de primitividade.

De acordo com Kierkegaard, falta à modernidade a experiência da primitividade. A tal privação o autor atribui o esquecimento moderno do que vem a ser a individualidade humana em sua realidade efetiva. Para o autor, a primitividade está fundamentalmente associada à possibilidade do indivíduo singular de adquirir uma impressão sobre si mesmo [no dinamarquês, Indtryk af sig selv] que não se apoie em comparações com os demais, nem em comportamentos habituais e normativos (SKS 27, 415-419; Papir, 369-370). Uma impressão sobre si mesmo só pode ser adquirida no singular, pois não há respostas gerais ou abordagens abstratas que forneçam uma honesta impressão sobre si; trata-se de uma indagação que deve ser respondida por cada um singularmente, sem que se valha de terceiros ou de mediações abstratas exteriores à subjetividade. Adquirir uma impressão sobre si é, portanto, atividade intransferível: "cada indivíduo deveria ter sua impressão primitiva da existência [Tilværelsen] - a fim de ser humano [være Menneske]" (SKS 27, 415, Papir, 369).

No sistema teatral elaborado por Stanislávski ao longo de suas investigações artísticas como encenador-pedagogo no Teatro de Arte de Moscou (TAM) e no Estúdio de Ópera e Drama encontramos como princípio fundamental

diversas que, em razão do stalinismo, foram agregadas sob a égide de um modelo único ligado ao sistema stanislavskiano, à revelia de seu próprio criador. Contudo, é possível reconhecer um traço pedagógico comum a esses encenadores: a preocupação com o processo de formação do artista e, mais especificamente, do ator e do diretor, cf. Maria Thais, s.d, Cadernos de Registro Macu (Pesquisas), caderno 08, p.16-17, acesso disponível pelo link: 
a exigência de um rigoroso "trabalho do ator sobre si mesmo". Não por acaso 0 trabalho do ator sobre si mesmo [no russo transliterado, Rabóta aktera nad soboi] é o título da obra de autoria de Stanislávski que apresenta a trajetória das investigações do encenador ao longo de sua carreira. A obra, dividida em dois volumes, teve sua primeira parte publicada em 1938, quando Stanislávski ainda vivia, e, a segunda postumamente, em 1948. ${ }^{23}$ O "trabalho sobre si" preconizado nessa investigação compreende que a arte da atuação dramática depende essencialmente do desenvolvimento de um processo de criação que aproxime a experiência concreta de vida do ator da persona, i.e., do personagem dramático ou papel a ser vivido pelo artista. Com essa abordagem, Stanislávski funda um novo paradigma para a atuação teatral, cujo legado é certamente dos mais valiosos e impactantes na história do teatro moderno. Esse novo paradigma tem por intuito abandonar a concepção tradicional da atuação teatral como representação, substituindo-a pela concepção de "a arte da experiência do vivo" [no russo transliterado, iskússtvo perejivánia]:

\begin{abstract}
Perejivánie, "experiência do vivo", "experiência", "vivência". A palavra, emprestada do coloquial perejivánie ("preocupar-se", "superar", "sofrer"), é composta do radical jít (viver) e de um prefixo que denota transição, transformação, transposição das fronteiras do meu próprio eu. Do eu mesmo em direção ao outro. Essa palavra transita entre diferentes campos semânticos, como projivánie (morada), ôpyt (experiência), emôtsia (emoção), entre outros (Nota da tradução, in Knebel, 2016, p.26).

Dentro do sistema teatral de Stanislávski perejivánie nos remete ao processo de experiência vivenciada no momento presente. O teatro como "a arte da experiência do vivo" [iskússtvo perejivánia] é precisamente a nova definição do teatro tal como imaginado por Stanislávski e pela escola russa. A sensação ou a vida que é experimentada aqui e agora são contrapostas ao teatro de representação, ou de imitação; trata-se de um teatro onde é necessário viver, e não parecer vivo. Nas línguas latinas, perejivánie é frequentemente traduzido de forma errada, como "reviver [uma experiência passada]". (...) É importante frisar que ele não deve ser entendido nunca como o resultado ao qual o ator aspira, mas como a própria fonte da ação, aquilo que literalmente o põe em movimento (Nota do Organizador, in Knebel, 2016, p.26).
\end{abstract}

Com efeito, a concepção stanislaviskiana da "arte da experiência do vivo"

${ }^{23}$ No Brasil, os dois volumes dessa obra foram traduzidos a partir da publicação norte-americana com os títulos: A preparação do ator e A Construção do Personagem, ambos pela Civilização Brasileira. 
nos convida a pensá-la em relação à noção de primitividade kierkegaardiana. Primeiramente, situa o encenador na posição do pedagogo, cujo propósito pode ser compreendido na mesma perspectiva indicada por Kierkegaard acerca da função ética da educação: da tarefa do professor de cultivar um movimento de "dentro para fora", levando à realização efetiva da capacidade individual. Tal "experiência do vivo" é também compreendida como esse movimento, como a "fonte da ação". Com essa premissa, o sistema de Stanislávski transformará visceralmente o modo como o ator irá se relacionar com a personagem dramática, e, portanto, com a literatura dramática.

A ação verbal é a pedra angular da arte dramática, a base da arte do ator em cena.

A capacidade de dizer em cena o texto do autor está intimamente ligada à habilidade do ator de pensar e revestir seus pensamentos com as palavras fornecidas pelo autor. A luta contra a pronúncia mecânica e a conquista do autêntico pensar em cena são tarefas que devem adquirir cada vez mais importância no trabalho de cada grupo teatral (Knebel, 2016, p.19, ênfases nossas).

Com efeito, seu método propõe meios para que a voz própria (ou seja, a individualidade singular) do ator encontre seu modo de expressar a voz da personagem dramática. Tais meios são constituídos por uma abordagem psicofísica, que envolve uma dimensão mental e racional, mas, fundamentalmente, física e sensível, em que o ator deve "sentir-se a si mesmo" [no russo, samotchúvstvie] ${ }^{24}$ em cena. Assim, essa escola russa rejeita categoricamente práticas comuns à tradição da representação teatral como a memorização mecânica prévia do texto, pois defende a apropriação psicofísica e orgânica do papel (Knebel, 2016, p.55). Com isso, sugerimos, nos termos de Kierkegaard, que o sistema de Stanislávski coloca o ator e o encenador frente ao desafio de experimentar a primitividade na arte dramática.

No que concerne ao trabalho pioneiro da autora estadunidense Winifred Ward no campo do Teatro-Educação, gostaríamos de destacar três aspectos

\footnotetext{
${ }^{24}$ No russo, samotchúvstvie, "sentir-se a si mesmo". "Essa palavra corresponde a uma das noções mais fundamentais do sistema de Stanislávski; nas línguas latinas, é frequentemente traduzida como 'estado' (em francês, por exemplo, état). [...] A ideia é enfatizar que o sentir-se a si mesmo denota sempre um certo 'movimento'” (Nota da Tradução, in Knebel, 2016, p 23).
} 
centrais. O primeiro refere-se ao fato de que Ward, embora tenha marcado de forma indelével toda a recepção norte-americana e britânica acerca das implicações epistemológicas e em políticas públicas sobre o aprendizado da arte dramática no ensino formal, consistindo, portanto, em referência indispensável para a pedagogia do teatro, lamentavelmente ainda não foi publicada no Brasil, dificultando sobremaneira o acesso aos meandros da originalidade do pensamento da autora. ${ }^{25} \mathrm{O}$ segundo aspecto diz respeito, propriamente, à importância de sua atuação para o reconhecimento da arte dramática enquanto campo disciplinar autônomo no âmbito do ensino fundamental. Nessa perspectiva, Ward propõe uma abordagem que, por um lado, não restringe o fenômeno teatral à noção de literatura dramática, senso comum em seu contexto histórico, e, por outro, qualifica e prestigia a experiência dramática infantil e juvenil enquanto fazer artístico, emancipando-a da trivialidade do desígnio instrumental a que frequentemente é submetida. Ward defende, com isso, o reconhecimento da arte dramática enquanto disciplina específica no currículo escolar, ainda que certamente favoreça o aprendizado de outros saberes:

Assim, por meio de peças sobre saúde, peças para aprimorar o inglês, peças sobre segurança, geografia, história e ciências, ela [a arte dramática] tornou-se escrava de todas as outras disciplinas escolares. Então, de fato, sua reputação foi arruinada! Ela não era reconhecida como arte [...] (Ward, 1930, p.6-7, nossas ênfases e tradução). ${ }^{26}$

Todavia, em contrapartida, Ward também enfatiza a relevância da literatura enquanto campo privilegiado para o crescimento artístico das crianças: "No entanto, nenhum material oferece tantas possibilidades de crescimento artístico como a literatura. A dramatização pode vitalizar e cristalizar o estudo de história,

${ }^{25}$ Sua obra mais consagrada é Creative Dramatics (For the Upper Grades and Junior Hight School), lançada há mais de 90 anos (WARD, 1930), seguida pelas não menos prestigiadas publicações Theatre for Children, de 1939, Playmaking with Children (from Kindergarten through Junior Hight School), de 1947, Stories to Dramatize, de 1952 (Ward, 1950; 1957; 1981). Embora ainda não tenhamos pesquisas de envergadura na obra de Winifred Ward no âmbito do Teatro- Educação no Brasil, podemos encontrar importantes perspectivas de abordagem da autora em Koudela, 1998 e Martins, 2017. Agradeço especialmente ao pesquisador Pedro Haddad Martins pelo acesso aos livros de referência (Ward, 1930; 1950; 1957; 1981), sem os quais a produção desse artigo não teria sido possível.

${ }^{26}$ No original: "So, by means of health plays and better English plays and safety-first plays and geography, history and science plays, she [a arte dramática] was made the slave of every other school subject. Then, indeed, was her reputation ruined! She was not recognizable as art (...)" (Ward, 1930, p.6-7, ênfases nossas). 
geografia, cidadania, mas seu melhor material é sem dúvida a literatura" (Ward, 1930, p. 4-5, nossas ênfases e tradução). ${ }^{27}$ Ainda, a autora rejeita a instrumentalização da arte dramática enquanto atividade usualmente associada à produção de espetáculos escolares, cuja principal motivação é a de suprir demandas associadas à celebração de eventos festivos, cívicos ou religiosos, sem que quaisquer preocupações artístico-pedagógicas próprias à teatralidade e suas especificidades formativas, no âmbito do aprendizado da criança e do adolescente, sejam investigadas, desenvolvidas e adotadas. Nesse sentido, o terceiro aspecto a ser destacado refere-se, precisamente, à filiação de seu pensamento a uma concepção filosófica e pedagógica moderna preconizada por autores como John Dewey, Francis Parker e William H. Kilpatrick que, grosso modo, compreende o propósito da educação infantil como um processo de aprendizagem, que articule integralmente o desenvolvimento das capacidades cognitivas, físicas e emocionais da criança. Por essa razão, a concepção pedagógica de Ward se opõe frontalmente a modelos didáticos de enfoque lógico-conceitual, cujos procedimentos fornecem parcos recursos expressivos a uma aquisição mais enriquecedora da experiência da criança com as especificidades da arte dramática enquanto forma particular de conhecimento de si e do mundo. Tais especificidades, como as noções de pantomima, enquanto ação eminentemente gestual, e, dramatização, enquanto ação gestual e discursiva, ambas fundadas na apropriação fabular de narrativas diversas, são exaustiva e metodicamente interpeladas pela autora que, com o mesmo desvelo, dedica-se à elaboração pedagógica de outras instâncias formais próprias à produção teatral, tais como: a direção (o repertório, a condução dos ensaios, a criação do espetáculo e o acompanhamento das apresentações), a concepção e a manufatura dos figurinos, da cenografia, da iluminação e da sonoplastia, bem como às adequações necessárias ao próprio edifício teatral (bastidores, ciclorama, altura e posição do palco, formas de uso das cortinas e da maquinaria teatral, dentre outros aspectos técnicos).

Considerando-se os três aspectos salientados acerca da obra de Ward, no

27 No material offers so many possibilities for artistic growth, however, as literature. Dramatization may vitalize and crystallize the study in history, geography, civics, but its best material is undoubtedly literature (Ward, 1930, p. 4-5, ênfases nossas). 
que tange ao escopo de nosso artigo, cabe observarmos que o corpo teórico e metodológico criado pela autora no âmbito da educação infantil, a partir do Drama Criativo [em inglês, Creative Dramatics], notoriamente interpela a conexão sui generis entre o desenvolvimento da expressão de si (em inglês, Selfexpression), enquanto apercepção de si (em inglês, Self-realization), e a experiência formativa da criança no campo da arte dramática (Ward, 1930, p.89). ${ }^{28}$ A peculiaridade dessa conexão é estabelecida, por sua vez, pelo fulcro ontológico da arte dramática que, conforme comentamos na seção 2, situa a face humana, ou seja, a dimensão singular do "eu" ou "si-mesmo", em uma relação dialética com a personagem dramática, isto é, a dimensão ficcional (literária ou imaginária) do "você" ou do "outro". Com efeito, levando em consideração a perspectiva de nossa abordagem, o fundamento dramático evocado pelas investigações de Ward inscreve-se de forma evidente no campo da comunicação indireta e, portanto, nos termos kierkegaardianos, da comunicação autenticamente ética, inserindo na efetividade do âmbito da instituição escolar um modus operandi artístico-pedagógico, que também sugerimos consonante ao conceito de primitividade.

\section{Reflexões sobre a possibilidade de aplicação da dialética da comunicação indireta no cultivo da arte dramática}

A mobilização ou o acesso à primitividade como forma de promover uma formação na arte dramática só encontra a sua viabilidade, segundo Kierkegaard, quando tal formação é promovida tendo em vista a própria constituição do ato comunicativo. É preciso enfatizar, contudo, que a comunicação indireta é reconhecida pelo filósofo dinamarquês como favorável - tanto para a mobilização e acesso à primitividade, quanto para esse processo formativo - em função de uma disposição do próprio conteúdo que deve ser comunicado.

\footnotetext{
28 Fizemos as opções tradutórias das noções de Self-expression e Self-realization respectivamente por "expressão de si" e "apercepção de si”, ao invés das mais usuais “autoexpressão" e "autorrealização", para enfatizar a determinação linguística, na língua inglesa, do termo Self, que coincide com o termo Selv, na língua dinamarquesa, enquanto "si" ou "si mesmo", noção filosófica fundamental no contexto do pensamento de Kierkegaard que, em A dialética da comunicação ética e ética-religiosa, é particularizada pela noção de um "eu-pessoal".
} 
Contrariamente a um tipo de formação ou de saber objetivo - e objetificante -, certos tipos de conhecimento resistem à comunicação direta em função de sua própria constituição original. É nesse sentido que Kierkegaard afirma que “a ciência talvez possa ser forçada para dentro de um ser humano; mas já em relação ao conhecimento estético (precisamente porque não há objeto), e ainda mais em relação ao ético (precisamente porque aqui, no sentido mais estrito, não há objeto), deve-se tirar à força de dentro dele" (SKS 27, 409; Papir 368:4). A suposta "ausência de objeto" nos conhecimentos estético e ético não corresponde a uma ausência de conteúdo, ao contrário, corresponde à resistência desses âmbitos a terem seus conteúdos condicionados e determinados pela posição de objetualidade, isto é, a posição em que o conteúdo é definido, para o indivíduo singular, a partir de uma definição e uma determinação externas a esse indivíduo. Em suma, se trata de encontrar uma maneira pela qual o "estético", o "ético" e o "ético-religioso" venham a ser determinados pelo indivíduo singular em uma relação dinâmica e produtiva com a sua própria existência.

Isso é precisamente a primitividade de que fala Kierkegaard: a instância e a disposição para onde deve se voltar o indivíduo singular ao buscar produzir para si um conteúdo que esteja necessariamente em relação com a sua própria existência. Kierkegaard é bastante assertivo no que diz respeito a esse ponto: "O ético e o ético-religioso devem ser comunicados existencialmente [existentielt] e em direção ao existencial [Existentielle]" (SKS 27, 427; Papir 371:1). O que à primeira vista poderia parecer um movimento paradoxal - em que o ponto de chegada é pressuposto no ponto de saída -, quando compreendido pela via da dinâmica da constituição existencial do indivíduo singular, indica a dialética que está presente na própria existência. Essa dialética é espelhada na comunicação, impondo à comunicação a impossibilidade de um acesso direto e, portanto, forçando com que toda "comunicação existencial" deva partir do pressuposto de que entre o comunicador e o receptor há ao menos dois abismos constitutivos: a) o abismo da existência do comunicador, que não tem como comunicar diretamente o Existencial em si, tendo sempre de indicar a direção desse Existencial pela singularidade de sua comunicação existencial; e b) o abismo da 
existência do receptor, que não pode apreender o Existencial a partir de um conteúdo objetivo e externo, devendo então ser levado à relação com a existência pela via de uma comunicação existencial que apela à sua própria singularidade.

A existência desses abismos, contudo, não expressa uma impossibilidade absoluta, mas um limite de possibilidades. A dialética da comunicação indireta pretende indicar a possibilidade de uma ponte - sempre instável e periclitante entre as individualidades singulares do comunicador e do receptor, apontando para o Existencial e, neste caso, para a primitividade.

Se pensarmos essa "ponte" como um campo de acontecimento, entendendo tanto a sua contingência quanto os limites de sua possibilidade constitutiva, temos então aqui a abertura para uma aplicação da dialética da comunicação indireta kierkegaardiana no cultivo e formação na arte dramática, ao menos nos termos avençados anteriormente com o subsídio de Stalisnávski e Ward. No caso de Stanislávski, a ideia de "trabalho sobre si" estaria intrinsecamente vinculada com a ideia da "arte da experiência do vivo", sendo aqui dado o campo de acontecimento em que comunicador e receptor coparticipam em uma formação que é existencial no sentido de suas singularidades. Considerando isso em termos kierkegaardianos, trata-se de encontrar uma relação comunicativa baseada em uma "comunicação de capacidade" ao invés de uma "comunicação de conhecimento". O caráter pragmático da "comunicação de capacidade" deve então ser visto como o estabelecimento de uma realidade efetivamente existencial na qual comunicador e receptor se encontram envolvidos. Para Kierkegaard, esse é o ponto central da efetivação da comunicação indireta: “A regra para a comunicação de capacidade é: começar a fazê-la imediatamente. Se o aprendiz disser: eu não posso, então o professor responde: Besteira, faça o melhor que pode. Assim começa o ensino. Seu fim é: ter capacidade. Mas o conhecimento não é comunicado" (SKS 27, 407; Papir 368:2). Por não comunicar um conhecimento, essa forma de comunicação indireta permite com que cada indivíduo desempenhe o "trabalho sobre si" com base em sua própria "experiência do vivo". O que comunica o professor, nesse caso, são os modos de acesso ou as aberturas para a primitividade. Em termos 
existenciais, isso acontece porque o próprio professor realiza efetivamente, em sua existência e, por conseguinte, em sua comunicação, o próprio campo do Existencial antes indicado. Uma vez que a questão se volta para a realidade efetiva de determinada capacidade, então o comunicador/professor deve estar imerso na própria realização existencial. Kierkegaard, com um exemplo aparentemente singelo, retorna ao epicentro dessa prática:

Ensinar a ser pobre na realidade efetiva é fazê-lo quando você mesmo é pobre (profiteri ${ }^{29}$ - no sentido de professar uma ciência, uma arte, e não ter lucro com isso). Nesse sentido, todo ensino termina em uma espécie de silêncio; pois quando o expresso existencialmente, minha fala não tem de ser audível (SKS 27, 410; Papir 368:7).

Não se trata meramente de um exemplo, como se o ensinamento, aqui, fosse a simples demonstração de um saber-fazer. Na sentença "ensinar a ser pobre", a ênfase recai antes em "ensinar a ser" do que necessariamente no complemento, uma vez que o conteúdo será a própria reflexividade ou duplicação que apresenta ao aluno/receptor a disposição da primitividade.

Em termos de cultivo ou formação na arte dramática, essa questão nos parece valiosa em ao menos dois pontos: por um lado, o comunicador/professor, ao comunicar uma capacidade, deve ele mesmo realizar efetivamente a própria arte dramática; por outro lado, nesta dinâmica de dupla-reflexão, o comunicador/professor deve se tornar a ocasião para o aparecimento do Existencial. Esses dois pontos acontecem concomitantemente e são necessariamente complementares. Kierkegaard parecia concordar com essa perspectiva, sobretudo no que diz respeito a certo privilégio da arte dramática na junção mais intensa entre essa comunicação de capacidade e o campo de acontecimento existencial. O cultivo da arte dramática é também o cultivo de uma relação existencial que deve colocar os envolvidos frente à primitividade.

Uma vez que consideramos esta estrutura pedagógica, chegamos então a uma última reflexão sobre a possibilidade de aplicação da dialética da comunicação indireta no cultivo da arte dramática. Segundo Ward, a arte 
dramática, enquanto um campo disciplinar autônomo, relaciona-se, em sua estrutura pedagógica, com outras diversas áreas. Para Ward, a literatura, principalmente, assume um importante papel na constituição dessa dimensão pedagógica da arte dramática, um ponto que é igualmente fundamental para a dialética da comunicação indireta kierkegaardiana. Por ser eminentemente uma comunicação de capacidade, pelo fato de não transmitir conteúdos de forma objetiva e direta, a literatura apela continuamente para a constituição de personagens que, segundo a posição kierkegaardiana, são a contínua reverberação da importância da constituição da personalidade para cada indivíduo singular ${ }^{30}$. A literatura é, em uma perspectiva muito específica, a contínua rememoração, para os receptores, de que ali um ou muitos "eus" expressam sua posição existencial. Kierkegaard é bastante explícito ao evidenciar como esse recurso serviu ao seu propósito filosófico existencial:

Um dos infortúnios da modernidade é de ter abolido o "eu" [Jeget], o eu pessoal. É precisamente por isso que a verdadeira comunicação éticoreligiosa desapareceu do mundo. Pois a verdade ético-religiosa se relaciona essencialmente com a personalidade [personlighed], só pode ser comunicada de um eu para um outro eu. Mas uma vez que a comunicação se torna objetiva, a verdade se torna inverdade. É para a personalidade que devemos nos voltar. E por isso considero como meu mérito que, ao colocar personalidades poéticas que dizem "eu" em meio à realidade efetiva da vida [Livets Virkelighed] (meus pseudônimos), contribuí para, se possível, acostumar meus contemporâneos a ouvirem um eu falar, um eu pessoal (não aquele eu puro fantástico e seu ventriloquismo). Mas, precisamente porque todo o desenvolvimento do mundo esteve o mais distante possível deste reconhecimento da personalidade é que isto deve ser feito poeticamente. A personalidade poética sempre tem algo que a torna mais palatável para um mundo que não está completamente acostumado a ouvir um "eu" (SKS 27, 428; Papir 371:1).

Por essa condição única, a arte dramática traz para dentro de si precisamente esse traço de intensificação que é próprio da literatura.

\footnotetext{
30 Para Kierkegaard, o desempenho da atividade de crítico literário não estava apartada de sua atuação enquanto filósofo. Seu primeiro livro publicado, Dos papéis de alguém que ainda vive, inicialmente uma resenha de um romance de traços românticos escrito por Hans Christian Andersen, tomava aquele exemplo literário como caso para desenvolver reflexões filosóficas que, no entanto, não deixavam de se relacionarem com uma reflexão pontual sobre a própria literatura. Nesse texto em questão, como em muitos outros, Kierkegaard critica os literatos que construíam narrativas ou personagens com base em ideias abstratas pré-condicionadas a fim de legitimarem ou argumentarem em prol dessas mesmas ideias. Para o filósofo, a literatura revelava sua potência precisamente quando a personagem literária revelasse uma personalidade que fosse, no fundo, a expressão de uma visão-de-vida [Livs-Anskuelse] existencial.
} 
Personagens que dizem “'eu' em meio à realidade efetiva da vida” são a ocasião de uma comunicação indireta em que o receptor é posto na relação dialética para com o Existencial. Ao enfatizar as especificidades próprias à arte dramática quando envolve o campo literário, como o faz Ward, a literatura é potencializada enquanto ocasião, uma vez que se multiplicam tanto os comunicadores quanto os receptores. O professor/comunicador se torna um receptor dos textos literários que, por sua vez, também estão dados para o aluno/receptor, isso tudo enquanto coexiste aí uma relação entre professor/comunicador e aluno/receptor. Em meio à prática da arte dramática, as personagens literárias são intensificadas em sua potência existencial precisamente porque aqueles praticantes constituem tais personagens como eco de sua própria constituição singular. A "personalidade poética" de que fala Kierkegaard é continuamente a ocasião para uma reflexão existencial em termos muito semelhantes aos pretendidos por Ward, uma vez que esta "personalidade poética" realiza o que autora norteamericana indica sobre o drama criativo: ela é uma experiência formativa que interpela a conexão sui generis entre o desenvolvimento da expressão de si (em inglês, Self-expression), enquanto apercepção de si (em inglês, Self-realization). A efetivação da literatura por meio da arte dramática é, portanto, uma forma de acesso à primitividade, sobretudo quando se considera que esses âmbitos - arte literária e dramática - são considerados não como um objeto determinado ou um conteúdo programaticamente concebido, mas como um campo de acontecimento do Existencial. Nos termos kierkegaardianos, a aplicação da dialética da comunicação indireta na base pedagógica de um pensamento sobre o cultivo da arte dramática leva à compreensão de que tal cultivo deve produzir uma "situação" [em dinamarquês, Situation]. Kierkegaard pontua que, "em relação à comunicação de capacidade estética, o professor e o aprendiz certamente formam uma situação" (SKS 27, 409; Papir 368:5). Se pensarmos o cultivo da arte dramática como o esforço pela produção dessa situação, então necessariamente estaremos pensando em um cultivo da arte dramática que se volta para a primitividade que implica, na constituição da singularidade dos indivíduos envolvidos, em um fazer dramático existencialmente potenciado. 


\section{Referências}

BERTHOLD, Margot. História Mundial do Teatro. São Paulo: Perspectiva, 2001.

HADOT, Pierre. O que é a filosofia antiga? Tradução de Dion Davi Macedo. São Paulo: Edições Loyola, 2004.

KIERKEGAARD, Søren. Søren Kierkegaards Skrifter. 28 vol. Ed. Niels-Jørgen Cappelørn et al. Copenhagen: Gad, 1997-2013.

KNEBEL, Maria. Análise-Ação: práticas das ideias teatrais de Stanislávski. Organização, adaptação e notas de Anatoli Vassíliev. Tradução e notas adicionais de Marina Tenório e Diego Moschkovitch. São Paulo: Ed. 34, 2016.

KOUDELA, Ingrid Dormien; ALMEIDA JR, José Simões. Léxico da Pedagogia do Teatro. São Paulo: Ed. Perspectiva: SP Escola de Teatro, 2015.

KOUDELA, Ingrid Dormien. Jogos Teatrais. São Paulo: Perspectiva, 1998.

LAZZARETTI, L. P. A crise e uma crise na vida de uma atriz, de Søren Kierkegaard. Cadernos de Literatura em Tradução, [S. l.], n. 22, p. 251-289, 2020. DOI: 10.11606/issn.2359-5388.i22p251-289. Acesso em: 27 jul. 2021.

LÜBCKE, Poul. Kierkegaard and Indirect Communication. In.: History of European Ideas. Vol. 12. No. 1, p.31-40, 1990.

MARTINS, Pedro Haddad. Pedagogia em performance: uma abordagem do ensino do teatro na escola básica. 2017. Tese (Doutorado em Pedagogia do Teatro) Escola de Comunicações e Artes, Universidade de São Paulo, São Paulo, 2017. Acesso em: 11 nov. 2020.

MOREIRA, Virginia. Da máscara à pessoa: a concepção trágica de homem. Revista de Ciências Sociais, Fortaleza, v. 25, p. 21-31, 1994.

PAVIS, Patrice. Dicionário de Teatro. São Paulo: Perspectiva, 1999.

ROSELFELD, Anatol. O Teatro Épico. São Paulo: Perspectiva, 2000.

MARIA THAIS. Cadernos de Registro Macu (Pesquisas), caderno 08, p. 16-17, s.d. Acesso disponível pelo link: https://www.macunaima.com.br/cadernos/caderno 08/caderno 08 dossie02.pdf

STANISLAVSKI, Konstantín. El trabajo del actor sobre si mismo en el proceso creador de la vivencia. Trad. Jorge Saura. 3a ed. Barcelona: Alba, 2010.

SÖDERQUIST, K. Brian. The Isolated Self. Irony as Truth and Untruth in Søren 
Kierkegaard's On the Concepto f Irony. Copenhagen: SKC; C.A. Reitzel, Ltd, 2007.

WARD, Winifred. Creative Dramatics. New York: D. Appleton and Company, 1930.

WARD, Winifred. Theatre for Children. Anchorage, Kentucky: The Childre's Theatre Press, 1950.

WARD, Winifred. Playmaking with Children (from Kindergarten through Junior High School). New York: Appleton-Century-Crofts, Inc., 1957.

WARD, Winifred. Stories to Dramatize. New Orleans: Anchorage Press, 1981.

VASCONCELLOS, Paulo Sérgio de. Persona poética e autor empírico na poesia amorosa romana. São Paulo: Editora Unifesp, 2016.

VOVOLIS, Thanos. Prosopon. The acoustical mask in Greek Tragedy and in Contemporary Theatre. Estocolmo: Dramatiska institutet, 2009.

Recebido em: 06/08/2021

Aprovado em: 29/10/2021 